\title{
Keragaman Genetik Kultivar Pisang Diploid (AA) Koleksi Cibinong Science Center Berdasarkan Marka RAPD dan ISSR
}

\section{Genetic Variation of Diploid Banana Cultivars (AA) from Collection of Cibinong Science Center Based on RAPD and ISSR Markers}

\author{
Yuyu Suryasari Poerba* dan Fajarudin Ahmad
}

Bidang Botani, Pusat Penelitian Biologi LIPI

Jl. Raya Bogor Km 46 Cibinong, Bogor 16911

E-mail: yyspoerba@yahoo.com *Penulis untuk korespondensi

\begin{abstract}
The banana (Musa acuminata Colla) is considered as an important crop plant due to its high economic value which also has good dietary source. Here, the genetic variation of 20 diploid (AA) banana cultivars from Cibinong Science Center collection were analyzed. Random amplified polymorphic DNAs (RAPDs) and Inter Simple Sequence Repeats fingerprinting of these banana cultivars were carried out by four primers of RPDSs and two primers of inter simple sequence repeats (ISSRs) led to DNA amplification. The amplification products of RPADs and ISSRs were polymorphic, $97.83 \%$ and $95 \%$, respectively. Size of the bands was varied from $350 \mathrm{bp}$ to $2.0 \mathrm{kbp}$. The range of genetic distance was from 0.06 to 0.07 . The molecular data showed that these banana varieties were diverse collection.
\end{abstract}

Key words: Musa acuminata, diploid, DNA fingerprinting, RAPD analysis, ISSR

\begin{abstract}
Abstrak
Pisang (Musa acuminata Colla) merupakan tanaman buah penting yang memiliki nilai ekonomi tinggi yang juga menjadi sumber bahan makanan. Pada penelitian ini keragaman genetik 20 kultivar pisang diploid (AA) koleksi Cibinong Science Center dianalisis. Sidikjari ke-20 kultivar pisang diploid ini dilakukan dengan empat primer Random amplified polymorphic DNA (RAPD) dan dua primer Inter Simple Sequence Repeats (ISSR) yang menghasilkan amplifikasi DNA. Produk amplifikasi RAPD dan ISSR menghasilkan pita-pita DNA yang plomorphic, masingmasing $97,83 \%$ dan $95 \%$. Ukuran pita DNA bervariasi dari 350 bp hingga 2,0Kbp. Kisaran jarak genetik dari 0,06 hingga 0,07. Data molekular ini menunjukkan ke-20 kultivar pisang diploid ini merupakan koleksi yang beragam.
\end{abstract}

Kata kunci: Musa acuminata, diploid, sidikjari DNA, analisis RAPD, ISSR

Diterima: 21 Juli 2009, disetujui: 21 September 2010

\section{Pendahuluan}

Pisang (Musa spp) merupakan salah satu buah-buahan penting di Indonesia. Kebanyakan pisang yang dapat dimakan berasal dari persilangan antara dua jenis diploid liar, Musa acuminata Colla (genom A) dan M. balbisiana Colla (genom B) (Simmonds dan Shepperd, 1955). Oleh karena itu, varietas budidaya pisang yang merupakan kombinasi dari genom yang berlainan dapat membentuk diploid $\mathrm{AA}, \mathrm{AB}$, triploid AAA, AAB, $\mathrm{ABB}$, dan tetraploid $\mathrm{AAAA}, \mathrm{AAAB}$ dan $\mathrm{ABBB}$, tergantung atas kelipatan kromosom dasar yang jumlahnya 11 .
Plasma nutfah pisang diploid AA yang terdiri atas berbagai forma dari jenis liar Musa acuminata dan berbagai varietas budidaya (kultivar) merupakan sumber gen untuk perbaikan genetik pisang (Crouch et al., 1999). Musa acuminata berasal dari Asia Tenggara dan Indonesia terdapat 15 varietas yang tersebar secara alami di berbagai daerah (Nasution, 1991). Varietas budidaya (kultivar) pisang diploid yang tergolong dalam genom AA memiliki banyak nama lokal dengan bentuk morfologi buah yang beragam. Pada penelitian ini digunakan 19 varietas budidaya pisang diploid AA dan satu varietas liar yaitu $M$. 
acuminata var malaccacensis yang terdapat di Cibinong Science Center (CSC) dengan menggunakan marka molekuler Random Amplified Polymorphic DNA (RAPD) dan Inter Simple Sequence Repeats (ISSR).

Penggunaan marka molekuler RAPD dalam studi keragaman genetik pisang banyak dilaporkan (Jain et al., 2007; Agoreyo et al., 2008; Bhat dan Jarret, 1995, Harirah dan Khalid, 2006; Ray et al., 2006). Demikian pula penggunaan marka molekuler ISSR pada pisang sering dilaporkan (Racharak dan Eiadthong, 2007; Ray et al., 2006; Lakshmanan et al., 2007). Kedua teknik ini memiliki keunggulan dalam pengerjaannya karena cost effective, sederhana dan relatif cepat, tanpa harus mengetahui terlebih dahulu pengetahuan awal genom, serta membutuhkan sedikit jumlah DNA genom. Kedua teknik ini, yang mengamplifikasi daerah genom yang berbeda, memungkinkan untuk mengidentifikasi keragaman genetik lebih baik dibandingkan hanya dengan satu teknik (Lakshmanan et al., 2007).

Penelitian ini bertujuan mempelajari keragaman genetik 20 kultivar pisang diploid (AA) koleksi CSC dengan menggunakan marka RAPD dan ISSR sebagai bahan acuan melihat hubungan kekerabatan genetik dengan Musa acuminata var malaccensis, yang memiliki ketahanan terhadap penyakit layu Fusarium.

\section{Metode Penelitian}

Duapuluh kultivar pisang diploid AA koleksi Cibinong Science Center digunakan dalam penelitian ini. Material DNA pisang berupa potongan daun muda yang dikeringkan dengan silika gel sesuai dengan pedoman pengumpulan sampel (Widjaya dan Poerba, 2004).

\section{Ekstraksi dan Isolasi DNA}

Ekstraksi DNA pisang dilakukan menggunakan metode CTAB (Dellaporta et al., 1983) yang dimodifikasi, dengan penambahan RNase sampai konsentrasi akhir $250 \mu \mathrm{g} / \mathrm{mL}$.

\section{Amplifikasi DNA}

Amplifikasi DNA dilakukan berdasarkan metode Williams et al., (1990) dengan menggunakan empat primer RAPD terpilih, yaitu OPA-18, OPA-13, OPN-06 dan OPN-12 (Operon Technology Ltd) dan dua primer ISSR (University of British Columbia, Canada), yaitu UBC 834 dan UBC 828, yang sebelumnya diuji dan menghasilkan pita polimorfik pada pisang. Reaksi PCR dilakukan pada volume total $15 \mu \mathrm{l}$ yang berisi $0,2 \mathrm{nM}$ dNTPs; $1 \mathrm{X}$ bufer reaksi; $2 \mathrm{mM} \mathrm{MgCl}_{2} ; 25$ ng DNA sample; 1 pmole primer tunggal; dan 1 unit Taq DNA polymerase (Promega) dengan menggunakan Thermocycler (Takara) selama 45 siklus. Pemanasan pertama pada suhu $94^{\circ} \mathrm{C}$ selama 2 menit, kemudian diikuti oleh 45 siklus yang terdiri atas denaturasi 1 menit pada suhu $94^{\circ} \mathrm{C}$, annealing 1 menit pada suhu $36^{\circ} \mathrm{C}$, dan 2 menit ekstensi pada suhu $72^{\circ} \mathrm{C}$. Setelah 45 siklus selesai, diikuti 5 menit proses ekstensi fragmen DNA pada suhu $72^{\circ} \mathrm{C}$ dan pendinginan pada suhu $25^{\circ} \mathrm{C}$. Hasil amplifikasi PCR divisualisasi pada gel agarosa 2,0\% dalam bufer TEA (Tris-EDTA) secara elektroforesis dengan menggunakan Mupid Mini Cell selama 50 menit pada 50 Volt. Kemudian direndam dalam larutan ethidium bromida dengan konsentrasi akhir $1 \mu \mathrm{l} / 100 \mathrm{ml}$ selama 10 menit. Hasil pemisahan fragmen DNA dideteksi menggunakan UV transluminator, kemudian difoto menggunakan kamera polaroid. Standar ukuran DNA 100 bp DNA ladder (Promega) untuk menetapkan ukuran pita hasil amplifikasi DNA.

\section{Analisis Data}

Marka yang dominan adalah RAPD, sehingga dianggap sebagai satu lokus putatif bialel (single biallelic locus) (Williams et al., 1990). Hanya lokus yang menunjukkan pita yang jelas yang digunakan untuk skoring: ada (1) dan kosong (0). Matriks binari fenotipe RAPD ini kemudian disusun untuk digunakan pada analisis matrik jarak genetik antarkultivar menggunakan "Nei's unbiased genetic distances" (Nei, 1978) dengan program POPGENE software (Yeh et al., 1999). Dendrogram dihasilkan dengan metode UPGMA (Unpaired) berdasarkan jarak genetik (Nei, 1978), dengan menggunakan prosedur NEIGBOR dari PHYLIP Versi 3.5. 


\section{Hasil dan Pembahasan}

\section{Profil RAPD}

Hasil amplifikasi total genom DNA dengan menggunakan empat primer RAPD pada 20 kultivar pisang diploid (AA) menghasilkan produk PCR yang dapat dibaca dan diskor, hasil analisisnya tertera pada Gambar 1 . Sekuens dari empat primer ini dan jumlah pita RAPD yang dihasilkan tertera pada Tabel 1. Pola pita DNA hasil elektroforesis menunjukkan bahwa setiap jenis primer menghasilkan pola pita-DNA berbeda pada beberapa sampel. Primer yang digunakan menghasilkan ukuran fragmen DNA hasil amplifikasi yang bervariasi (Tabel 1), tertinggi (200-2000 bp) diperoleh pada primer OPA-18, dan paling rendah pada OPA-13.

Hasil pengamatan menunjukkan bahwa diperoleh 46 fragmen DNA berukuran dari 200 bp sampai 2,0 kb, dengan 97,83\% merupakan pita polimorfik. Primer OPA-18 menghasilkan pita DNA tertinggi yaitu 15 , sedangkan primer OPA-13 menghasilkan jumlah pita DNA paling sedikit yaitu 6. Jumlah maksimum pita polimorfik 15 terdapat pada primer OPA-18 (Tabel 1).

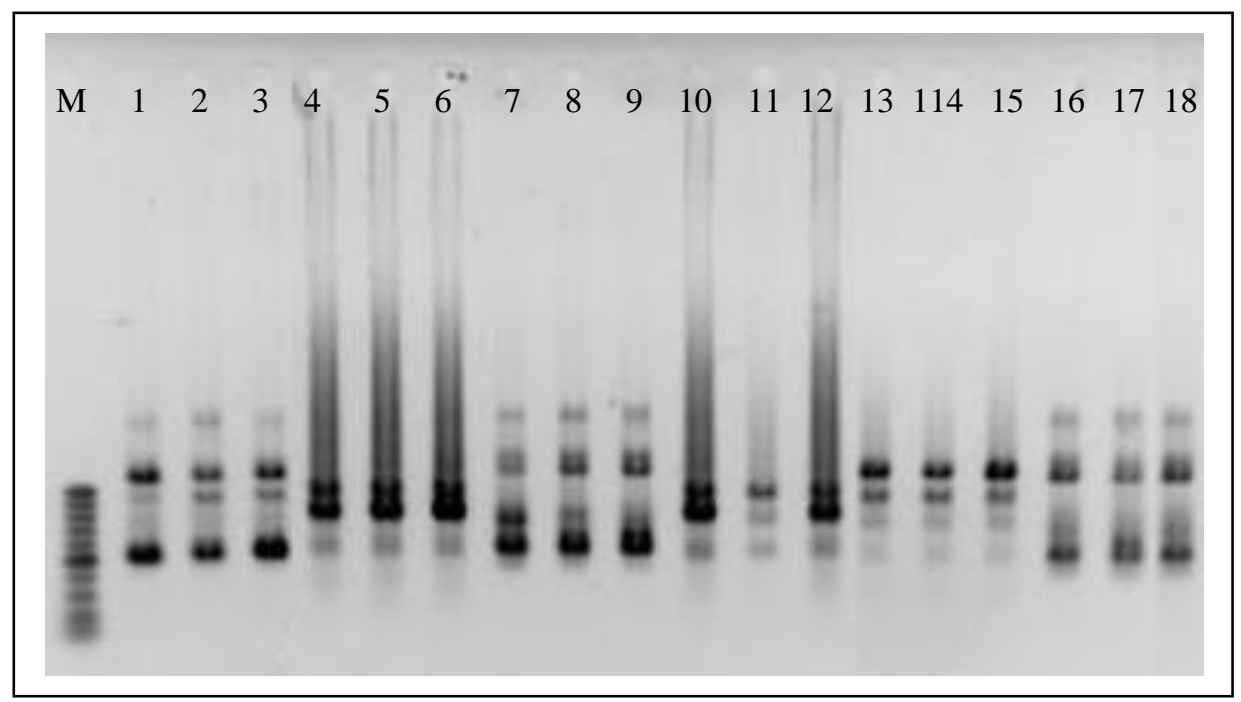

Gambar 1. Hasil PCR kultivar pisang diploid (AA) dengan OPA-18.

Keterangan: $\mathrm{M}=$ Marker (100-bp DNA ladder, Promega), 1-3 = Musa acuminata var malaccensis; $4-6=$ Mas 40 hari; $7-9=$ rejang forest, $10-12=$ mas jalil (AA); $13-15=$ mas beranjut; $16-18=$ rejang kampong.

Tabel 1. Primer yang digunakan dan jumlah pita DNA hasil amplifikasi pada 20 kultivar pisang diploid (AA).

\begin{tabular}{|c|c|c|c|c|c|c|}
\hline $\begin{array}{l}\text { Kode } \\
\text { Primer }\end{array}$ & $\begin{array}{l}\text { Urutan Basa } \\
5^{\prime}-3^{\prime}\end{array}$ & $\begin{array}{c}\text { Jumlah } \\
\text { Pita }\end{array}$ & $\begin{array}{l}\text { Jumlah Pita } \\
\text { Polimorfik }\end{array}$ & & $\begin{array}{l}\text { Ukuran Pita } \\
\text { (bp) }\end{array}$ & Fragmen Spesifik \\
\hline OPA-13 & CAGCACCCAC & 6 & 5 & $83,33 \%$ & $300-1600$ & $\begin{array}{l}\text { OPA-13 } 3_{500} \text { pada kultivar mas } \\
\text { muli }\end{array}$ \\
\hline OPA-18 & AGGTGACCGT & 15 & 15 & $100,0 \%$ & $200-2000$ & - \\
\hline OPN-06 & GAACGGACTC & 11 & 11 & $100,0 \%$ & $250-2000$ & $\begin{array}{l}\text {-OPN-06550 pada kultivar no } 37 ? \\
\text { Pisang madu }\end{array}$ \\
\hline OPN-12 & CACAGACACC & 14 & 14 & $100,0 \%$ & $300-1700$ & - \\
\hline & & 46 & 45 & $\mathbf{9 7 , 8 3 \%}$ & & \\
\hline
\end{tabular}


Beberapa fragmen DNA hasil amplifikasi spesifik hanya terdapat pada kultivar tertentu, seperti yang terlihat pada Gambar 2 dan Tabel 2.

\section{Profil ISSR}

Hasil amplifikasi total genom DNA dua primer ISSR pada 20 kultivar pisang diploid menghasilkan produk PCR yang dapat dibaca dan diskor, sehingga hasilnya dapat dianalisis (Gambar 3). Sekuens dari dua primer ini dan jumlah marka ISSR yang dihasilkan tertera pada Tabel 2. Primer yang digunakan menghasilkan ukuran fragmen DNA hasil amplifikasi yang bervariasi. Variasi tertinggi (400-1800 bp) diperoleh pada primer UBC-834, dan paling rendah pada UBC 826. Hasil pengamatan menunjukkan bahwa diperoleh 20 fragmen DNA yang berukuran 350-1800 bp, dengan 95\% merupakan pita polimorfik. Primer UBC-834 menghasilkan pita DNA tertinggi yaitu 11 , sedangkan primer UBC-826 paling sedikit yaitu 9. Jumlah maksimum pita polimorfik 11 terdapat pada primer UBC-834 (Tabel 3).

\section{Analisis Gabungan RAPD dan ISSR}

Nilai jarak genetik 20 kultivar pisang diploid (AA) berdasarkan 46 marka RAPD dan 20 marka ISSR berkisar antara 0,06 dan 0,7 (Tabel 2). Dari kombinasi 190 pasangan dari 20 kultivar, kultivar mas (7) dan mas teropong (8) memiliki nilai jarak genetik yang paling rendah $(0,06)$, sedangkan kultivar mas 40 hari (3) dan bangkahulu (13) memiliki jarak genetik yang tertinggi $(0,7)$.

Analisis kluster yang dilakukan terhadap data gabungan marka RAPD dan marka ISSR menghasilkan dendrogram yang memisahkan ke 20 kultivar ke dalam dua kluster yang berbeda. Kluster pertama (A) terdiri atas tiga kultivar yaitu Musa acuminata var malaccencis (1), mas kirana (12) dan bangkahulu (13). Kluster kedua (B) terbagi lagi dua subkluster. Subkluster pertama (D) terdiri atas 13 kultivar, dan subkluster kedua (E) terdiri atas 4 kultivar, yaitu: rejang forest (5), rejang barangan (6), mas penjalin (18) dan rejang kampung (16) (Gambar 3). Semua kultivar dalam subkluster $E$ ini memiliki bentuk tandan dan buah yang mirip satu dengan yang lain (Gambar 4).

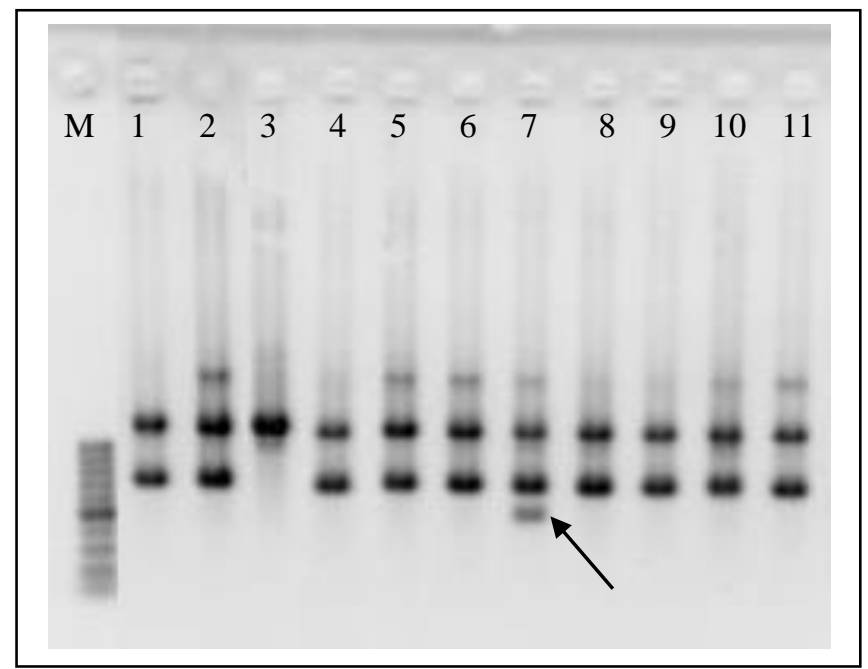

Gambar 2. Hasil PCR pada beberapa aksesi pisang diploid yang menunjukkan fragmen spesifik dengan primer OPN-13.

Keterangan: $\mathrm{M}=$ marker, $1=$ bangkahulu, $2=$ mas soponyono, $3=$ Musa acuminata $\mathrm{sp}$ malaccensis, $4=$ pisang papan, $5=$ rejang kampung, $6=$ mas 40 hari, $7=$ mas muli, $8=$ rejang $/$ mas penjalin, $9=$ mas raja, $10=$ mas jambe, $11=$ rejang forest . 


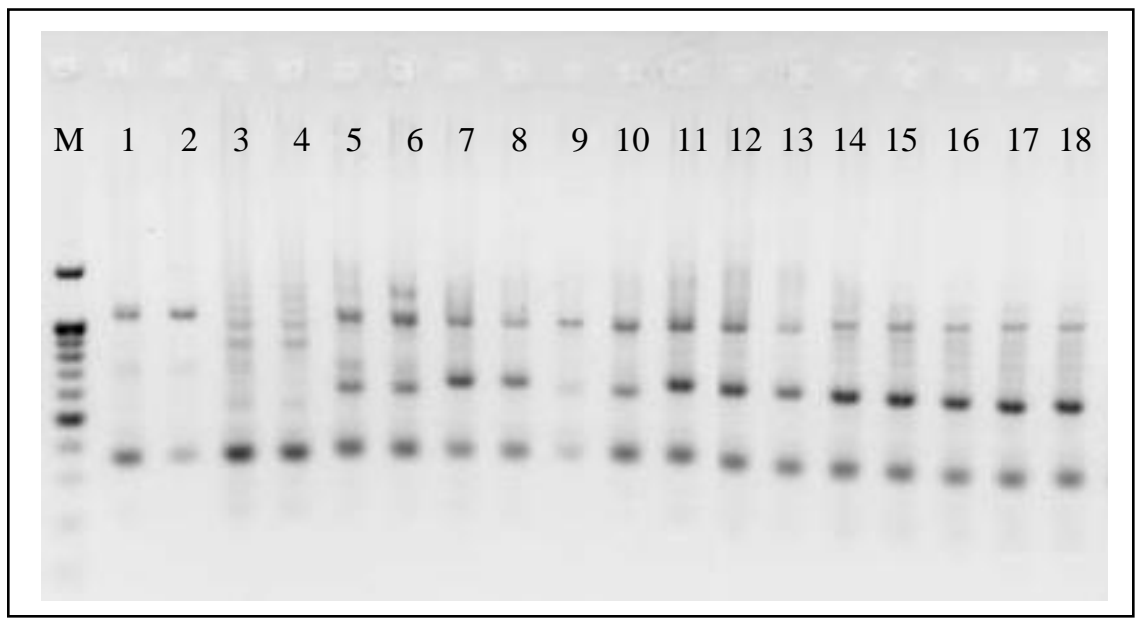

Gambar 3. Hasil PCR beberapa kultivar pisang diploid (AA) dengan primer UBC-834.

Keterangan: $\mathrm{M}=100$ bp DNA marker (Promega), $1-2=$ Musa acuminata var malaccensis, $3-4=$ mas palembang, $5-6=$ mas penjalin, $7-8=$ mas jalil, $9-10=$ rejang barangan, $11-12=$ mas biasa, $13-14=$ mas teropong, $15-16=$ mas cijeruk, $17-18=$ mas besar

Tabel 2. Matrik jarak genetik 20 kultivar pisang diploid (AA) koleksi Cibinong Science Center.

\begin{tabular}{|c|c|c|c|c|c|c|c|c|c|c|c|c|c|c|c|c|c|c|c|}
\hline & 1 & 2 & 3 & 4 & 5 & 6 & 7 & 8 & 9 & 10 & 11 & 12 & 13 & 14 & 15 & 16 & 17 & 18 & 1920 \\
\hline 1 & "**** & & & & & & & & & & & & & & & & & & \\
\hline 2 & 0.41 & $* * *$ & & & & & & & & & & & & & & & & & \\
\hline 3 & 0.5 & 0.43 & $* * *$ & & & & & & & & & & & & & & & & \\
\hline 4 & 0.39 & 0.27 & 0.3 & $* * *$ & & & & & & & & & & & & & & & \\
\hline 5 & 0.39 & 0.42 & 0.37 & 0.34 & $* * *$ & & & & & & & & & & & & & & \\
\hline 6 & 0.41 & 0.35 & 0.39 & 0.3 & 0.12 & $* * *$ & & & & & & & & & & & & & \\
\hline 7 & 0.4 & 0.37 & 0.29 & 0.2 & 0.31 & 0.3 & $* * *$ & & & & & & & & & & & & \\
\hline 8 & 0.44 & 0.38 & 0.31 & 0.21 & 0.29 & 0.28 & 0.06 & $* * *$ & & & & & & & & & & & \\
\hline 9 & 0.43 & 0.27 & 0.37 & 0.17 & 0.34 & 0.33 & 0.16 & 0.18 & $* * *$ & & & & & & & & & & \\
\hline 10 & 0.44 & 0.25 & 0.35 & 0.15 & 0.35 & 0.38 & 0.18 & 0.19 & 0.08 & $* * *$ & & & & & & & & & \\
\hline 11 & 0.41 & 0.32 & 0.36 & 0.2 & 0.36 & 0.32 & 0.16 & 0.17 & 0.17 & 0.18 & $* * *$ & & & & & & & & \\
\hline 12 & 0.35 & 0.42 & 0.5 & 0.44 & 0.4 & 0.45 & 0.54 & 0.55 & 0.5 & 0.48 & 0.48 & $* * *$ & & & & & & & \\
\hline 13 & 0.5 & 0.5 & 0.7 & 0.6 & 0.64 & 0.65 & 0.62 & 0.63 & 0.56 & 0.57 & 0.54 & 0.5 & $* * *$ & & & & & & \\
\hline 14 & 0.42 & 0.39 & 0.32 & 0.26 & 0.3 & 0.36 & 0.3 & 0.27 & 0.26 & 0.28 & 0.36 & 0.52 & 0.51 & $* * *$ & & & & & \\
\hline 15 & 0.51 & 0.4 & 0.37 & 0.35 & 0.44 & 0.51 & 0.42 & 0.43 & 0.42 & 0.43 & 0.37 & 0.48 & 0.49 & 0.33 & $* * *$ & & & & \\
\hline 16 & 0.45 & 0.43 & 0.41 & 0.41 & 0.08 & 0.2 & 0.38 & 0.36 & 0.41 & 0.42 & 0.43 & 0.35 & 0.6 & 0.37 & 0.38 & $* * *$ & & & \\
\hline 17 & 0.41 & 0.29 & 0.36 & 0.23 & 0.36 & 0.35 & 0.26 & 0.24 & 0.27 & 0.28 & 0.29 & 0.45 & 0.46 & 0.25 & 0.3 & 0.37 & $* * *$ & & \\
\hline 18 & 0.3 & 0.37 & 0.41 & 0.35 & 0.13 & 0.22 & 0.32 & 0.3 & 0.32 & 0.33 & 0.34 & 0.27 & 0.54 & 0.31 & 0.45 & 0.17 & 0.31 & *** & \\
\hline 19 & 0.36 & 0.4 & 0.18 & 0.16 & 0.31 & 0.33 & 0.19 & 0.25 & 0.27 & 0.25 & 0.26 & 0.44 & 0.66 & 0.37 & 0.38 & 0.38 & 0.33 & $\begin{array}{r}2 \\
0.3\end{array}$ & $* * *$ \\
\hline 20 & 0.41 & 0.35 & 0.29 & 0.3 & 0.36 & 0.39 & 0.3 & 0.28 & 0.33 & 0.31 & 0.32 & 0.45 & 0.58 & 0.42 & 0.4 & 0.4 & 0.26 & 4 & $0.26 * * *$ \\
\hline
\end{tabular}

Keterangan: 1 = Musa acuminata var malaccensis, $2=$ mas palembang, $3=$ mas 40 hari, $4=$ mas jalil, $5=$ rejang forest, $6=$ rejang barangan , $7=$ mas biasa, $8=$ mas teropong, $9=$ mas cijeruk, $10=$ mas besar, $11=$ berlin, $12=$ mas kirana, $13=$ bangkahulu/pisang uli, $14=$ mas soponyono, $15=$ pisang papan, $16=$ rejang kampung, $17=$ mas muli, $18=$ mas penjalin; $19=$ mas raja; $20=$ mas jambe .

Tabel 3. Primer ISSR yang digunakan dan jumlah pita DNA hasil amplifikasi pada 20 kultivar pisang diploid (AA).

\begin{tabular}{ccccccc}
\hline \hline Kode Primer & $\begin{array}{c}\text { Urutan Basa Jumlah Pita } \\
\text { 5, - 3 }\end{array}$ & $\begin{array}{c}\text { Jumlah pita } \\
\text { Polimorfik }\end{array}$ & Ukuran Pita (bp) & Fragmen Spesifik \\
\hline \hline UBC-826 & $(\mathrm{AC})_{8} \mathrm{C}$ & $\mathbf{9}$ & $\mathbf{8}$ & & $\mathbf{3 5 0}-\mathbf{1 5 0 0}$ & - \\
UBC-834 & $(\mathrm{AG})_{8} \mathrm{YT}$ & $\mathbf{1 1}$ & $\mathbf{1 1}$ & & $\mathbf{4 0 0 - 1 8 0 0}$ & - \\
\hline \hline Jumlah & & $\mathbf{2 0}$ & $\mathbf{1 9}$ & $\mathbf{9 5 \%}$ & & \\
\hline \hline
\end{tabular}




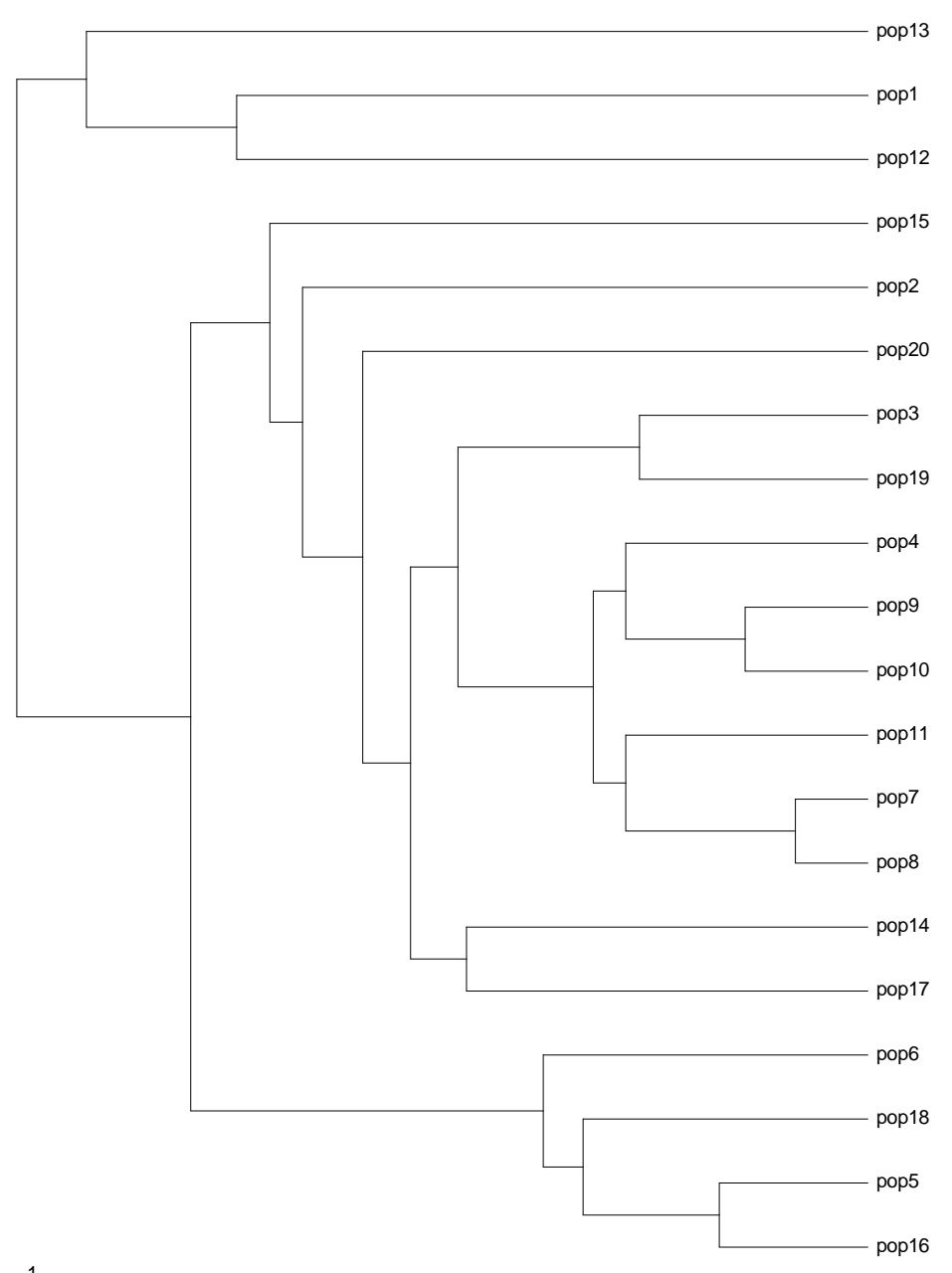

Gambar 4. Dendrogram jarak genetik 20 kultivar pisang

Keterangan: No $1=$ Musa acuminata var malaccensis, $2=$ mas palembang, $3=$ mas 40 hari, $4=$ mas jalil, $5=$ rejang forest, $6=$ rejang barangan, $7=$ mas, $8=$ mas teropong, $9=$ mas cijeruk, $10=$ mas besar, $11=$ berlin, $12=$ mas kirana, $13=$ bangkahulu/pisamh uli, $14=$ mas soponyono, $15=$ pisang papan, $16=$ rejang kampung, $17=$ mas muli, $18=$ mas penjalin; $19=$ mas raja; $20=$ mas jambe.

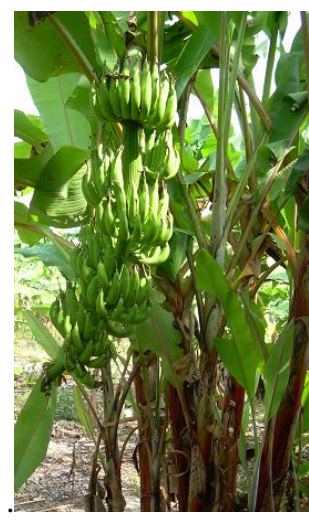

Mas penjalin (18)

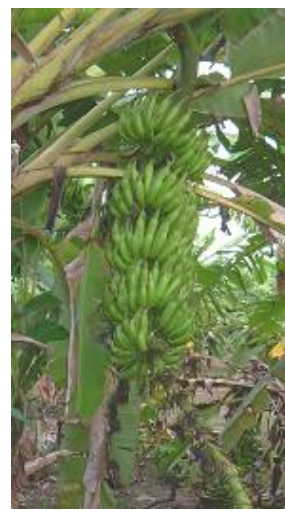

Rejang forest (5)

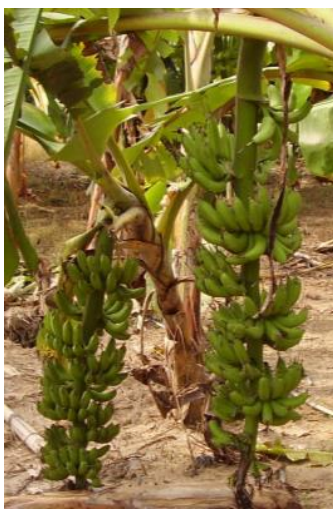

Rejang barangan (6)

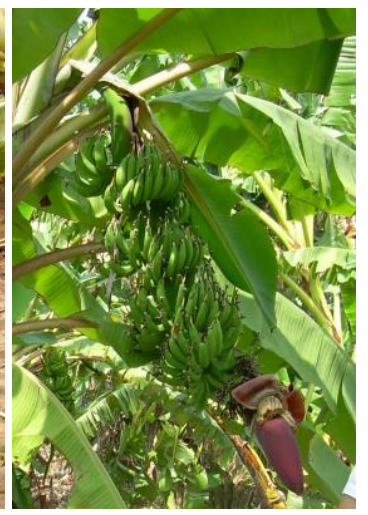

Rejang kampung (16) 
Gambar 5. Penampilan tandan buah pisang diploid AA.

Jumlah dan intensitas pita DNA yang dihasilkan setelah amplifikasi DNA dengan PCR sangat tergantung cara primer mengenal urutan DNA komplementernya pada cetakan DNA (DNA template) yang digunakan (Tingey et al., 1994). Hasil amplifikasi DNA pada 20 kultivar pisang diploid ini dengan menggunakan empat primer RAPD dan dua primer ISSR di atas tidak selalu memperoleh pita dengan intensitas yang sama. Intensitas pita DNA hasil amplifikasi pada setiap primer sangat dipengaruhi oleh kemurnian dan konsentrasi DNA cetakan. DNA cetakan yang mengandung senyawa seperti polisakarida dan senyawa fenolik, serta konsentrasi DNA cetakan yang terlalu kecil sering menghasilkan pita DNA amplifikasi yang redup atau tidak jelas (Weeden et al., 1992). Selain itu, sebaran situs penempelan primer pada DNA cetakan dan adanya kompetisi tempat penempelan primer pada DNA cetakan yang menyebabkan satu fragmen diamplifikasi dalam jumlah banyak dan fragmen lainnya sedikit. Proses amplifikasi mungkin diinisiasi pada beberapa tempat, tetapi hanya beberapa set yang dapat dideteksi sebagai pita sesudah diamplifikasi (Weeden et al., 1992). Pemilihan primer pada analisis keragaman genetik berpengaruh terhadap polimorfisme pita yang dihasilkan, karena setiap primer memiliki situs penempelan tersendiri. Akibatnya pita DNA polimorfik yang dihasilkan setiap primer menjadi berbeda, baik dalam ukuran banyaknya pasang basa maupun jumlah pita DNA.

Tingginya kisaran nilai jarak genetik menunjukkan bahwa kultivar pisang diploid AA memiliki keragaman genetik yang cukup tinggi. Hal ini mengindikasikan adanya keragaman genetik pada kelompok genom AA yang mungkin disebabkan oleh adanya rekombinasi genetik yang terjadi. Keragaman genetika yang terjadi dalam subkelompok AA ini mengindikasikan bahwa beberapa diploid AA merupakan hibrid alami. Namun, analisis lebih lanjut perlu dilakukan lagi dengan menggunakan varietas liar lainnya atau dengan menggunakan marka molekular yang lebih banyak. Keragaman genetik yang tersedia ini dapat dijadikan sumberdaya genetik yang tersedia untuk pemuliaan pisang, khususnya sebagai induk jantan dalam persilangan dengan tetraploid untuk menghasilkan pisang triploid.

\section{Simpulan dan Saran}

\section{Simpulan}

Keempat marka RAPD dan dua marka ISSR telah berhasil digunakan untuk mengkaji keragaman genetik kultivar pisang diploid (AA) koleksi CSC. Masing-masing 97,83\% dan 95\% dari produk hasil PCR dengan menggunakan marka RAPD dan ISSR yang merupakan pita DNA polimorfik. Ukuran pita DNA yang dihasilkan bervariasi dari 350bp hingga 2,0 kbp. Nilai jarak genetik diantara kombinasi kultivar yang diamati berkisar antara 0,06 dan 0,7 yang menunjukkan koleksi pisang diploid yang sangat beragam.

\section{Saran}

Keragaman genetik yang tersedia ini dapat dijadikan sumberdaya genetik yang tersedia untuk pemuliaan pisang, khususnya sebagai induk jantan dalam persilangan dengan tetraploid untuk menghasilkan pisang triploid yang tahan terhadap Fusarium. Namun untuk mendapatkan gambaran lebih lengkap mengenai keragaman genetik, penelitian perlu dilanjutkan dengan menggunakan primer yang lebih banyak dan/atau dengan menggunakan primer yang lain dengan jumlah populasi serta jumlah individu dalam populasi lebih banyak.

\section{Ucapan Terima Kasih}

Penulis mengucapkan terima kasih kepada Pusat Penelitian Biologi -LIPI yang telah mendanai penelitian ini melalui Sub Kegiatan Perbaikan Kajian Genetika Buah-buahan Indonesia Tahun 2008. Terima kasih juga disampaikan kepada Sdri. Herlina yang telah membantu penelitian ini.

\section{Daftar Pustaka}

\footnotetext{
Agoreyo, B.O., Golden, K.D. dan Brown, S.E. 2008. Analysis of Genetic Variability Among plantain Cultivars (Musa paradisiaca L.) using Arbitrarily Primed PCR Technique. African J. Biotechnology, 7 (8): 1041-1045.
} 
Bhat, K.V. dan Jarret, R.L. 1995. Random Amplified Polymorphic DNA and Genetic Diversity in Indian Musa Germplasm. Genet. Resour. Crop Evol., 42: 107-118.

Crouch, J.H., Crouch, H.K., Tenkouano, A. dan Ortiz, R. 1999. VNTR-based Diversity Analysis of 2x and $4 \mathrm{x}$ full-sib Musa hybrids. Electronic $J$. Biotechnology $\mathrm{Vol}$ 2. Issue 3. Available on line at http://www.ejbiotechnology.info/content/vol10/ issue $1 /$ full/12.

Dellaporta, S.L., Wood, J. dan Hicks, J.B. 1983. A plant DNA minipreparation. Version II. Plant Molecular Biology Reporter, 4: 19-21.

Harirah, A.A. dan Khalid, N. 2006. Direct Regeneration and RAPD Assessment of Male Inflorescence Derived Plants of Musa acuminata cv. berangan. Asia Pacific J. Molecular Biology and Biotechnology, 14 (1): 11-17.

Jain, P.K., Saini, M.L., Pathak, H. dan Gupta, P.K. 2007. Analysis of Genetic Variation in Different Banana (Musa species) Variety Using Random Amplified Polymorphic DNAs (RAPDs). African J. Biotechnology, 6 (17):1987-1989.

Lakshmanan, V., Venkataramareddy, S.R. dan Neelwarne, B. 2007. Molecular Analysis of Genetic Stability in Long-term Micropropagated Shoots of Banana using RAPD and ISSR Markers. Electronic J. Biotechnology 10 (1). Available on line at http://www. ejbiotechnology. info/content/vol10/issue1/full/12.

Nasution, R.E. 1991. A Taxonomic Study of The Musa acuminata Colla with its Intraspecific Taxa in Indonesia. Memoirs of the Tokyo University of Agriculture, Vol 32.

Nei, M. 1978. Estimation of Average Heterozygosity and Genetic Distance from a Small Numbers of Individuals. Genetics, 89: 583-590.

Racharak, P. dan Eiadthong, W. 2007. Genetic Relationship Among Subspecies of Musa acuminate Colla and A-genome Consisting Edible Cultivared Bananas Assayed with ISSR Markers.
Songklanakarin J. Sci. Technol., 29 (6): 1479-1489.

Ray, T., Indrajit, I., Saha, P., Sampa, D.A.S. dan Roy, S.C. 2006. Genetic Stability of Three Economically Important Micropropagated Banana (Musa spp.) Cultivars of Lower Indo-Gangetic Plains, as Assessed by RAPD and ISSR markers. Plant cell, tissue and organ culture, 85 (1):11-21.

Simmonds, N.W. dan Shepherd, K. 1955. The Taxonomy and Origins of the Cultivated Bananas. Linnean Society. Botanical J., 55: 302-312.

Tingey, S.V., Rafalski J.A. dan Hanafey, M.K. 1994. Genetic Analysis with RAPD Markers. In: Coruzzi, C. dan Puidormenech, P. (Eds.). Plant Molecular Biology. Belin, Springer-Verlag.

Weeden, N.F., Timmerman, G.M., Hemmat, M., Kneen, B.E. dan Lodhi, M.A. 1992. Inheritance and Reliability of RAPD Markers. Application of RAPD Technology to Plant Breeding. Joint Plant Breeding Symposia Series CSSA/ ASHS/ AGA. Minneapolis, 1 November 1992.

Widjaya, E.A. dan Poerba, Y.S. 2004. Pengumpulan Data Plasma Nutfah dan Genetika. In: Rugayah, E.A., Widjaya dan Praptiwi (Eds.). Pedoman Pengumpulan Data Keanekaragaman Flora. Pusat Penelitian Biologi -LIPI. 113-140.

Williams, J.G., Kubelik, A.R., Livak, K.J., Rafalsky, J.A. dan Tingev, S.V. 1990. DNA Plolymorphism Amplified by Arbitrary Primers are Useful as Genetic Markers. Nucleic Acid Research, 18 (22): 6531-6535.

Yeh, F.C., Yang, R.C. dan Boyle, T. 1999. Popgene Version 1.31. Microsoft Windows-based Freeware for Population Genetic Analysis. Available at: http://www.ualberta.ca/ fyeh/ download.htm. 